
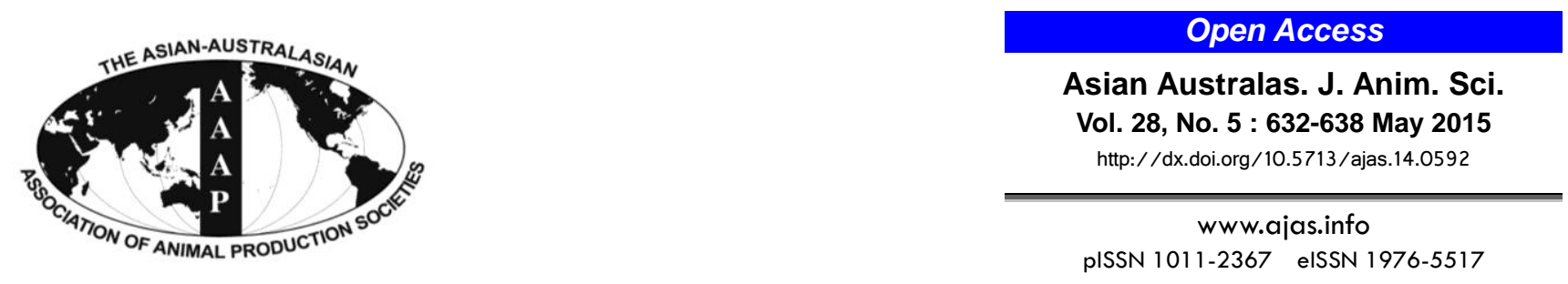

\title{
Characteristics of Wet and Dried Distillers Grains on In vitro Ruminal Fermentation and Effects of Dietary Wet Distillers Grains on Performance of Hanwoo Steers
}

\author{
Ill Young Kim ${ }^{\mathrm{a}}$, Gyu Chul Ahn ${ }^{1, a}$, Hyung Jun Kwak, Yoo Kyung Lee ${ }^{2}$, Young Kyoon $\mathrm{Oh}^{2}$, \\ Sang Suk Lee ${ }^{3}$, Jeong Hoon Kim ${ }^{4}$, and Keun Kyu Park ${ }^{1, *}$ \\ College of Animal Bioscience and Technology, Konkuk University, Seoul 143-701, Korea
}

\begin{abstract}
Two experiments were conducted to evaluate the nutrient composition, in vitro dry matter disappearance (IVDMD) and organic matter disappearance (IVOMD) of three kinds of distillers grains (DG); i) wet distillers grains (WDG, KRW 25/kg), ii) dried distillers grains (DDG, KRW 280/kg), iii) dried distillers grains with solubles (DDGS, KRW 270/kg) produced from tapioca $70 \%$ and rice $30 \%$, and to evaluate dietary effects of WDG on the performance of Hanwoo steers. In Exp. 1, twelve-WDG, four-DDG and oneDDGS were collected from seven ethanol plants. Average crude protein, crude fiber, neutral detergent fiber, and acid detergent fiber of WDG, DDG, and DDGS were: $32.6 \%, 17.8 \%, 57.5 \%$, and $30.2 \%$ for WDG, $36.7 \%, 13.9 \%, 51.4 \%$, and $30.5 \%$ for DDG, and $31.0 \%$, $11.9 \%, 40.3 \%$, and $21.2 \%$ for DDGS (DM basis), respectively. The DDGS had a higher quantity of water-soluble fraction than WDG and DDG and showed the highest IVDMD $(\mathrm{p}<0.05)$ in comparison to others during the whole experimental time. The IVDMD at 0 to 12 $\mathrm{h}$ incubation were higher $(\mathrm{p}<0.05)$ in DDG than WDG, but did not show significant differences from 24 to $72 \mathrm{~h}$. The same tendency was observed in IVOMD, showing that DG made from tapioca and rice (7:3) can be used as a feed ingredient for ruminants. Considering the price, WDG is a more useful feed ingredient than DDG and DDGS. In Exp. 2, 36 Hanwoo steers of 21 months $(495.1 \pm 91 \mathrm{~kg})$ were randomly assigned to one of three dietary treatments for 85 days; i) Control (total mixed ration, TMR), ii) WDG 10\% (TMR containing $10 \%$ of WDG, as fed basis), and iii) WDG $20 \%$ (TMR containing $20 \%$ of WDG, as fed basis). With respect to body weight and average daily gain, there were no differences between control and WDG treatments during the whole experimental period. Dry matter intake of control $(9.34 \mathrm{~kg})$, WDG $10 \%(9.21 \mathrm{~kg})$ and $20 \%(8.86 \mathrm{~kg})$ and feed conversion ratio of control (13.0), WDG 10\% (13.2) and $20 \%$ (12.1) did not show differences between control and WDG treatments. Thus, the use of WDG up to 20\% in TMR did not show any negative effect on the performance of Hanwoo steers. (Key Words: Hanwoo, Steers, Total Mixed Ration, Distillers By-products, Wet Distillers Grains)
\end{abstract}

\section{INTRODUCTION}

Wet distillers grains (WDG), dried distillers grains

\footnotetext{
* Corresponding Author: Keun-kyu Park. Tel: +82-2-450-3661, Fax: +82-2-455-1044, E-mail: kkpark@konkuk.ac.kr

1 Animal Resources Research Center, College of Animal Bioscience and Technology, Konkuk University, Seoul 143-701, Korea.

${ }^{2}$ National Institute of Animal Science, Suwon, 441-706, Korea.

3 Department of Animal Science and Technology, Sunchon National University, Sunchon 540-950, Korea.

${ }^{4}$ Cargill Agri Purina, Seongnam 463-808, Korea.

${ }^{a}$ These two authors contributed equally to this work.

Submitted Aug. 4, 2014; Revised Nov. 3, 2014; Accepted Dec. 5, 2014
}

(DDG) and dried distillers grains with solubles (DDGS) are by-products from ethanol production processing. Fiber, protein and fat are concentrated approximately 3 -fold in distillers grains (DG) when starch is fermented to produce ethanol, thus DG can replace the protein source in diets of cattle (Klopfenstein et al., 2008). Because of the increasing production of DDGS, studies to evaluate DDGS as a protein source have been widely conducted. However, in United States, the source of these by-products was mostly DDGS from wheat and corn (Shurson et al., 2005), with limited data available about the usefulness of WDG and DDG as feed ingredients for ruminants.

There were nine ethanol production companies in Korea

Copyright $@ 2015$ by Asian-Australasian Journal of Animal Sciences This is an open-access article distributed under the terms of the Creative Commons Attribution Non-Commercial License (http://creativecommons.org/licenses/by-nc/3.0/), which permits unrestricted non-commercial use, distribution, and reproduction in any medium, provided the original work is properly cited. 
in 2012, and WDG, DDG, and DDGS productions were 34,700, 13,880 and 7,000 t, respectively (Statistics Korea, 2014). The amount of WDG, DDG, and DDGS was equivalent to 6.6 billion Korean won (KRW) per year (2012). Unlike the case of the United States, almost all WDG, DDG, and DDGS produced in Korea are from tapioca and rice. Four out of nine ethanol plants had drying facilities for DG, thus the greatest amount of DG produced by ethanol plants in Korea within a year is WDG. The DDGS contribute the smallest amount of DG from ethanol plants because there was only one ethanol plant in Korea that produces DDGS. In addition, due to the absence of a drying process for WDG, the price of WDG (KRW 25/kg) is lower than DDG (KRW 280/kg) and DDGS (KRW 270/kg). The WDG have a nutritional and economic advantage over DDGS if managed correctly, and have greater energy concentrations, less heat damaged protein (because of the absence of drying process), and lower price per unit of dry matter (DM) compared with DDGS (Dooley et al., 2008). However, because of a higher water portion than DDG and DDGS, WDG have disadvantages such as greater transportation cost, difficult storage and handling, and a reduced shelf life (Lemenager et al., 2006). Thus, coensiling WDG with other feed sources such as a total mixed ration (TMR) can result in a safe way to store WDG for long periods of time (Buckmaster et al., 2008)

Waldo et al. (2009) reported that DDGS from wheat and corn was an excellent protein source for ruminants, but there was little or no data available concerning the characteristics and nutritional quality of WDG from tapioca $70 \%$ and rice $30 \%$. In Korea, all of DG (WDG, DDG, and DDGS) are from tapioca and rice (most common ratio, 7:3), but to our knowledge, there are no published data on the use of these DG in the diets of beef cattle. Therefore, the purposes of this study were to i) investigate the nutritional value of WDG, DDG, and DDGS from tapioca $70 \%$ and rice $30 \%$, and ii) evaluate the ability of WDG as a feed ingredient of TMR for Hanwoo steers in early to midfattening period.

\section{MATERIALS AND METHODS}

Exp. 1. Chemical analysis and in vitro dry matter and organic matter disappearances of WDG, DDG, and DDGS

WDG, DDG, and DDGS: The WDG, DDG, and DDGS were obtained from seven commercial ethanol plants (EP-1 to 7 ; located in Korea) producing alcoholic liquors and medical disinfectant. The samples collected in this study were eleven-WDG, four-DDG, and one-DDGS. The WDG samples from EP-1 (A and B) and 2 (A, B, C, and D) were collected from the same ethanol plant at different months (EP-1 A and B, during November and December; EP-7 A to
D, during March and December).

Chemical analysis: All WDG, DDG, and DDGS samples for chemical analysis were dried at $55^{\circ} \mathrm{C}$ (relatively low temperature to prevent browning reaction of protein) in a forced-air oven connected to a sucking fan for over 24 hours and ground through $1 \mathrm{~mm}$ screen using Wiley mill. Dry matter, crude protein (CP), ether extract (EE, crude fat), crude fiber (CF), and ash contents were analyzed by procedures of the AOAC (1999), whereas neutral detergent fiber (NDF) and acid detergent fiber contents were analyzed according to the procedure of Van Soest et al. (1991).

Amino acid analysis for glycine, alanine, cysteine, valine, methionine, isoleucine, leucine, histidine, lysine, and arginine of three-WDG and one-DDG were performed using an automatic amino acid analyzer (Amino acid analyzer S430, Sykam, Eresing, Germany) Calcium (Ca) and phosphorus (P) of three-WDG and one-DDG were analyzed by the procedure of the AOAC (1999), and alcohol residue was analyzed by automatic alcohol detector (AntonPaar DMA 4500, Ashland, VA, USA).

In vitro dry matter and organic matter disappearances: In vitro experiments were conducted to determine the in vitro dry matter disappearance (IVDMD) and in vitro organic matter disappearance (IVOMD) of WDG, DDG, and DDGS. The substrates used in this study (five-WDG, fourDDG, and one-DDGS) were ground through a Wiley mill to pass a $1 \mathrm{~mm}$ screen. A modified Tilley and Terry (1963) procedure was performed for the in vitro system. Ruminal fluid was obtained from a ruminally fistulated $(120 \mathrm{~mm})$ Hanwoo steer $(568 \mathrm{~kg})$ fed a 1:4 forage:concentrate diet. Ruminal fluid was strained through eight-layers of cheese cloth and flushed with $\mathrm{CO}_{2}$-saturated gas for $5 \mathrm{~min}$ to maintain anaerobic condition. After $\mathrm{CO}_{2}$ gas injection, ruminal fluid was transported immediately to the laboratory in a pre-warmed thermos maintained at $39^{\circ} \mathrm{C}$. To measure IVDMD and IVOMD, approximately $0.5 \mathrm{~g}$ of substrate (WDG, DDG, and DDGS) was weighed and placed in triplicate $50 \mathrm{~mL}$ centrifuge tubes fitted with gas release hole (diameter, $0.5 \mathrm{~mm}$ ).

The inoculum was prepared by diluting the rumen fluid with McDougall's buffer in a 1:4 ( $\mathrm{vol} / \mathrm{vol})$ ratio. After adding inoculum $(40 \mathrm{~mL})$ to the centrifuge tube, $\mathrm{CO}_{2}$ saturated gas was injected for five seconds to maintain anaerobic condition in the tube. Two blanks (only inoculum without substrate) were included in each incubation time. The tubes incubated in a shaking water bath with constant oscillation (80 rpm) at $39^{\circ} \mathrm{C}$ for $0,4,8,12,24,48$, and $72 \mathrm{~h}$ incubation times. After each incubation time, distilled water and filter paper (No. 417, VWR, Radnar, PA, USA) was used for rinsing the incubation tube and washing the residue. The residue on the filter paper was dried in a forced-air oven at $105^{\circ} \mathrm{C}$ for over 24 hours and weighed to determine the dry matter disappearance, and burned in a furnace 
$\left(550^{\circ} \mathrm{C}\right.$, over 5 hours; Muffle furnace, Daisan General Firm, Seoul, Korea) and weighed to determine the organic matter disappearance.

Calculations and statistical analysis: The IVDMD (\%) was calculated as $100 \times($ [dry weight of initial sample residue -blank]/dry weight of initial sample) and IVOMD (\%) was calculated as $100 \times$ ([weight of organic matter of initial sample - residue - blank]/weight of organic matter of initial sample). Data obtained from in vitro experiments (IVDMD and IVOMD) were subjected to statistical analysis using the GLM procedure of SAS (SAS Institute, 2002; version 9.01). Data were analyzed by analysis of variance and Duncan's multiple range tests were used to determine significant differences $(\mathrm{p}<0.05)$ among the treatments within each classification.

\section{Exp. 2. Effects of dietary WDG on performance of Hanwoo steers}

Experimental design: Thirty six Hanwoo steers of 21

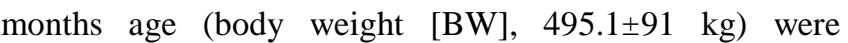
randomly divided into three groups of 12 each and assigned to one of the three dietary treatments for 85 days (initial to mid-fattening period); i) Control (TMR), ii) WDG $10 \%$ (TMR containing $10 \%$ of WDG, as fed basis), and iii) WDG $20 \%$ (TMR containing $20 \%$ of WDG, as fed basis). The formulation and chemical composition of experimental diets for each treatment are shown in Table 1. The steers were housed in sawdust bedding-surfaced pens (4 steers/pen; 8.0 $\mathrm{m}$ wide $\times 8.0 \mathrm{~m}$ length $=64 \mathrm{~m}^{2} /$ pen; $16 \mathrm{~m}^{2} /$ steer; $8.0 \mathrm{~m}$ wide linear bunk space) and were marked with a numbered tag in their ear. Feeds were offered equally at 06:00, 12:00, and 18:00 $\mathrm{h}$ on daily basis. They were allowed to access fresh water and mineral block without any restriction during the whole experimental period. Steers were weighed at initial, mid and final days before morning feeding of the whole experimental period. Dry matter intake (DMI) was measured every week for calculating feed conversion ratio (FCR).

Calculations and statistical analysis: Nitrogen-free extract (NFE), total digestible nutrients (TDN) and FCR value of experimental feeds were calculated as follows: i) $\mathrm{NFE}=\% \mathrm{DM}-(\% \mathrm{EE}+\% \mathrm{CP}+\%$ ash $+\% \mathrm{CF})$. ii $) \mathrm{TDN}=$ $0.93 \times \mathrm{CP}+0.92 \times(1+\mathrm{EE}-$ ash $-\mathrm{CP}-\mathrm{NDF})+0.75 \times(\mathrm{NDF}-$ acid detergent lignin $[\mathrm{ADL}]) \times\left(1-\mathrm{ADL}^{2 / 3} /(\mathrm{NDF})^{2 / 3}\right)($ Conrad et al., 1984). iii) $\mathrm{FCR}=$ dry matter intake $(\mathrm{kg}) / \mathrm{gain}(\mathrm{kg})$.

Data obtained from the in vivo trial (BW, average daily gain [ADG], DMI, and FCR) were subjected to statistical analysis using the general linear model (GLM) procedure of SAS (SAS Institute, 2002; version 9.01). Data were analyzed by analysis of variance and Duncan's multiple range tests were used to determine significant differences $(\mathrm{p}<0.05)$ among treatments.
Table 1. Ingredients and chemical composition of TMR

\begin{tabular}{lccc}
\hline Items $(\%)$ & Control & WDG & WDG \\
& & $10 \%$ & $20 \%$ \\
\hline Concentrates & 40.00 & 40.00 & 38.50 \\
WDG & 0.00 & 10.00 & 20.00 \\
Starch pulp & 25.00 & 20.00 & 7.00 \\
Corn gluten feed & 9.76 & 5.53 & 5.81 \\
Corn flake & 5.87 & 7.89 & 8.99 \\
Alfalfa hay & 1.50 & 1.50 & 1.50 \\
Tall fescue & 2.00 & 2.00 & 2.00 \\
Rye grass & 7.04 & 7.48 & 7.05 \\
Oat hay & 2.00 & 2.00 & 2.00 \\
Water & 5.40 & 2.10 & 5.60 \\
Fermentation starter & 0.60 & 0.60 & 0.60 \\
Limestone & 0.83 & 0.90 & 0.95 \\
Total & 100 & 100 & 100 \\
Chemical composition $(D M$ & & \\
DM & $685 i s, \%)$ & & 65.9 \\
CP & 15.2 & 67.6 & 15.4 \\
EE & 4.7 & 15.3 & 4.6 \\
Ash & 11.5 & 11.5 & 13.0 \\
CF & 10.5 & 10.0 & 10.8 \\
Ca & 1.77 & 1.54 & 1.74 \\
P & 0.52 & 0.47 & 0.46 \\
NDF & 44.2 & 43.5 & 44.3 \\
ADF & 18.8 & 20.2 & 20.5 \\
TDN & 65.8 & 65.2 & 63.6 \\
\hline
\end{tabular}

TMR, total mixed rations (as fed basis); WDG, wet distillers grains; DM, dry matter; $\mathrm{CP}$, crude protein; $\mathrm{EE}$, ether extract; $\mathrm{CF}$, crude fiber; NDF, neutral detergent fiber; ADF, acid detergent fiber; TDN, total digestible nutrients.

${ }^{1}$ Corn (23.7\%), Corn gluten feed (18.52\%), Ground wheat (10\%), Copra meal $(10 \%)$, Corn starch $(9 \%)$, Palm kernel cake $(8.66 \%)$, Rice bran $(6 \%)$, Soybean hull (3.4\%), Molasses $(5 \%)$, Salt $(0.32 \%)$, Limestone $(1.95 \%)$, Porphyry $(1.6 \%)$, CMS $(1.5 \%)$, Vitamin premix $(0.2 \%)$, Mineral premix $(0.15 \%)$

${ }^{2}$ Complex of lactic acid bacteria.

\section{RESULTS AND DISCUSSIONS}

Exp. 1. Chemical analysis and in vitro dry matter and organic matter disappearances of WDG, DDG, and DDGS

The average nutrient composition and concentration of amino acids of WDG, DDG, and DDGS in this study are shown in Table 2 and 3, respectively. All WDG, DDG, and DDGS were produced from a blend of approximately $70 \%$ of tapioca and $30 \%$ of rice (7:3) in this study. Average DM of WDG, DDG, and DDGS were $23.1 \%, 93.2 \%$, and $86.9 \%$, respectively. Average CP concentrations of WDG, DDG, and DDGS were 32.6\%, 36.7\%, and 31.0\% (DM basis), respectively. Waldo et al. (2009) reported that DDGS from wheat or corn (wheat $100 \%$, corn $100 \%$ or blended [wheat $70 \%$ and corn $30 \%]$ ) are a good protein source (CP, 32\% to $39 \%$, DM basis) for growing and finishing cattle. In our 
Table 2. Chemical composition of WDG, DDG, and DDGS from different ethanol plants

\begin{tabular}{|c|c|c|c|c|c|c|c|c|c|c|c|}
\hline \multirow{2}{*}{ Contents } & \multirow{2}{*}{\multicolumn{2}{|c|}{$\begin{array}{c}\text { Ethanol } \\
\text { plant }\end{array}$}} & \multicolumn{9}{|c|}{ Chemical composition (\%) } \\
\hline & & & DM & $\mathrm{CP}$ & $\mathrm{EE}$ & $\mathrm{CF}$ & Ash & $\mathrm{NDF}$ & $\mathrm{ADF}$ & NFE & TDN \\
\hline \multirow[t]{12}{*}{$\overline{\text { WDG }}$} & $\mathrm{EP}^{1}-1$ & $\mathrm{~A}$ & 23.0 & 34.0 & 8.9 & 16.8 & 6.5 & 57.7 & 28.7 & 33.7 & 41.1 \\
\hline & & $\mathrm{B}$ & 25.5 & 37.0 & 9.4 & 11.1 & 5.7 & 59.6 & 31.0 & 36.8 & 41.3 \\
\hline & EP-2 & & 21.0 & 32.6 & 3.2 & 17.6 & 6.4 & 42.9 & 28.8 & 40.1 & 42.0 \\
\hline & EP-3 & & 25.9 & 32.3 & 3.6 & 20.1 & 13.0 & 52.3 & 31.8 & 31.6 & 39.3 \\
\hline & EP-4 & & 28.0 & 32.5 & 6.1 & 20.2 & 6.8 & 58.0 & 30.7 & 31.4 & 41.7 \\
\hline & EP-5 & & 25.8 & 27.6 & 4.5 & 11.5 & 6.7 & 60.7 & 33.4 & 33.4 & 41.4 \\
\hline & EP-6 & & 25.5 & 36.4 & 5.0 & 22.6 & 3.9 & 61.7 & 26.0 & 26.0 & 42.8 \\
\hline & EP-7 & A & 19.8 & 29.3 & 4.2 & 19.7 & 10.2 & 59.6 & 29.7 & 36.6 & 36.9 \\
\hline & & B & 18.1 & 40.4 & 9.1 & 17.8 & 7.8 & 59.4 & 29.7 & 24.9 & 37.0 \\
\hline & & $\mathrm{C}$ & 19.9 & 26.5 & 3.5 & 17.3 & 4.9 & 59.5 & 30.7 & 47.8 & 38.8 \\
\hline & & $\mathrm{D}$ & 21.2 & 30.2 & 2.4 & 20.9 & 8.2 & 61.2 & 31.9 & 38.3 & 37.8 \\
\hline & & Mean & 23.1 & 32.6 & 5.4 & 17.8 & 7.3 & 57.5 & 30.2 & 34.6 & 40.0 \\
\hline \multirow[t]{5}{*}{ DDG } & EP-1 & A & 92.7 & 33.6 & 7.4 & 12.4 & 8.8 & 43.3 & 25.2 & 37.8 & 37.0 \\
\hline & & B & 94.5 & 35.9 & 5.4 & 13.3 & 7.3 & 56.2 & 33.0 & 38.1 & 37.8 \\
\hline & EP-2 & & 93.5 & 37.7 & 2.1 & 13.1 & 3.6 & 47.3 & 28.1 & 43.5 & 39.5 \\
\hline & EP-3 & & 92.0 & 39.6 & 3.5 & 16.6 & 11.9 & 58.9 & 35.8 & 28.4 & 36.3 \\
\hline & & Mean & 93.2 & 36.7 & 4.6 & 13.9 & 7.9 & 51.4 & 30.5 & 37.0 & 37.7 \\
\hline DDGS & EP-4 & & 86.9 & 31.0 & 3.7 & 11.9 & 10.7 & 40.3 & 21.2 & 42.7 & 36.8 \\
\hline
\end{tabular}

WDG, wet distillers grains; DDG, dried distillers grains; DDGS, dried distillers grains with solubles; DM, dry matter; CP, crude protein; EE, ether extract; CF, crude fiber; NDF, neutral detergent fiber; ADF, acid detergent fiber; NFE, nitrogen-free extract; TDN, total digestible nutrients.

${ }^{1}$ Types of ethanol plant, 1 to 7 ; A to D, replication with different sampling dates.

study, CP concentrations of WDG, DDG, and DDGS from tapioca $70 \%$ and rice $30 \%$ ranged from $27 \%$ to $40 \%$, thus showed similar protein concentrations to DDGS from wheat or corn. Likewise, Quinn et al. (2011) found the average CP concentration of WDG from $70 \%$ corn and $30 \%$ sorghum was $30.0 \%$ (DM basis). According to May et al. (2010), WDG showed greater CP concentration (33.4\%) from a blend of corn $90 \%$ and sorghum $10 \%$ grains than WDG

Table 3. Concentrations of amino acids and major minerals in WDG and DDG

\begin{tabular}{|c|c|c|c|c|}
\hline \multirow{3}{*}{$\begin{array}{l}\text { Items } \\
(\mathrm{mg} / \mathrm{kg})\end{array}$} & \multicolumn{3}{|c|}{ WDG } & \multirow{3}{*}{$\frac{\text { DDG }}{\text { EP-1 }}$} \\
\hline & \multirow{2}{*}{$\mathrm{EP}^{1}-1$} & \multicolumn{2}{|c|}{ EP-7 } & \\
\hline & & $\mathrm{A}$ & B & \\
\hline Glycine & 0.44 & 0.25 & 1.19 & 0.45 \\
\hline Alanine & 0.50 & 0.25 & 1.31 & 0.49 \\
\hline Cysteine & 0.84 & 0.50 & 0.62 & 0.81 \\
\hline Valine & 0.53 & 0.27 & 1.50 & 0.52 \\
\hline Methionine & 1.04 & 0.47 & 0.76 & 0.99 \\
\hline Isoleucine & 0.36 & 0.21 & 1.06 & 0.37 \\
\hline Leucine & 0.61 & 0.33 & 1.82 & 0.61 \\
\hline Histidine & 0.27 & 0.23 & 0.65 & 0.23 \\
\hline Lysine & 0.25 & 0.18 & 1.07 & 0.20 \\
\hline Arginine & 0.20 & 0.00 & 1.85 & 0.31 \\
\hline Calcium (\%) & 0.16 & 0.35 & 0.42 & 0.16 \\
\hline Phosphorus (\%) & 0.26 & 0.40 & 0.43 & 0.40 \\
\hline
\end{tabular}

WEG, wet distillers grains; DDG, dried distillers grains

${ }^{1}$ Types of ethanol plant, 1 and 7; A and B, replication with different sampling date. from corn $70 \%$ and sorghum $30 \%(\mathrm{CP}, 30.0 \%)$.

According to the NRC (2000), methionine and lysine concentrations of corn are 0.24 and $0.21 \mathrm{mg} / \mathrm{kg}$, respectively. In our study, concentrations of WDG were 0.47 (EP-7 A) to 1.04 (EP-1) for methionine, and 0.18 (EP7 A) to 1.07 (EP-7 B) for lysine. Thus, WDG from tapioca and rice showed higher methionine and lysine concentrations than corn. There was no alcohol detected from WDG and DDG in this study. Itabashi et al. (1991) reported that alcohol concentration over $5 \%$ in the diet reduced ruminal fermentation of beef cattle.

The IVDMD and IVOMD of WDG, DDG, and DDGS are shown in Table 4 and 5, respectively. The DDGS had a higher quantity of water-soluble fraction than WDG and DDG, thus showed higher IVDMD (37.3\%) than WDG $(12.8 \%)$ and DDG $(20.3 \%)$ at early incubation time (4 h; $\mathrm{p}<0.05)$, and showed the highest IVDMD throughout the whole incubation time ( 0 to $72 \mathrm{~h}, \mathrm{p}<0.05)$. The WDG showed lower IVDMD than DDG at 0 to 12 hours of incubation $(\mathrm{p}<0.05)$, but WDG and DDG did not show significant differences from 24 to 72 hours of incubation. The same tendency was observed in IVOMD. Likewise, Smith et al. (2013) reported that IVDMD of WDG from a blend of approximately $70 \%$ corn and 30\% sorghum did not show statistical differences between control and WDG treatments $(12.5 \%, 25.0 \%$, and $37.5 \%$, DM basis). These results showed that WDG, DDG, and DDGS from tapioca and rice (7:3) can be used as a feed ingredient for protein source in ruminants. In addition, considering its low price, 
Table 4. Effects of dietary WDG, DDG, and DDGS on in vitro DMD (\%) from different ethanol plants and sampling dates

\begin{tabular}{|c|c|c|c|c|c|c|c|c|c|}
\hline \multirow{2}{*}{ Contents } & \multirow{2}{*}{\multicolumn{2}{|c|}{ Ethanol plant }} & \multicolumn{7}{|c|}{ In vitro $\mathrm{DMD}(\%)$} \\
\hline & & & $0 \mathrm{~h}$ & $4 \mathrm{~h}$ & $8 \mathrm{~h}$ & $12 \mathrm{~h}$ & $24 \mathrm{~h}$ & $48 \mathrm{~h}$ & $72 \mathrm{~h}$ \\
\hline \multirow[t]{6}{*}{ WDG } & $E P^{1}-1$ & $\mathrm{~A}$ & $11.15^{\mathrm{f}}$ & $13.81^{\mathrm{c}}$ & $19.19^{\mathrm{c}}$ & $21.37^{\mathrm{e}}$ & $27.51^{\mathrm{de}}$ & $38.72^{f}$ & $39.40^{\mathrm{e}}$ \\
\hline & & B & $12.99^{\mathrm{e}}$ & $15.05^{\mathrm{c}}$ & $13.77^{\mathrm{d}}$ & $25.20^{\mathrm{d}}$ & $26.54^{\mathrm{e}}$ & $39.00^{\mathrm{ef}}$ & $39.83^{\mathrm{e}}$ \\
\hline & EP-2 & & $7.07^{\mathrm{g}}$ & $14.54^{\mathrm{c}}$ & $18.40^{\mathrm{cd}}$ & $23.99^{\mathrm{d}}$ & $43.37^{\mathrm{a}}$ & $48.34^{\mathrm{bc}}$ & $56.22^{\mathrm{a}}$ \\
\hline & EP-3 & & $5.07^{\mathrm{i}}$ & $10.94^{\mathrm{d}}$ & $15.23^{\mathrm{cd}}$ & $20.68^{\mathrm{e}}$ & $32.08^{b c}$ & $45.03^{\mathrm{cd}}$ & $52.18^{\mathrm{b}}$ \\
\hline & EP-4 & & $7.59^{\mathrm{g}}$ & $9.58^{\mathrm{d}}$ & $16.49^{\mathrm{cd}}$ & $18.47^{\mathrm{f}}$ & $30.42^{\mathrm{cd}}$ & $47.24^{\text {bcd }}$ & $47.75^{\mathrm{c}}$ \\
\hline & & Mean & $8.77^{\mathrm{C}}$ & $12.78^{\mathrm{C}}$ & $16.62^{\mathrm{C}}$ & $21.94^{\mathrm{C}}$ & $31.98^{\mathrm{B}}$ & $43.67^{\mathrm{B}}$ & $47.08^{\mathrm{B}}$ \\
\hline \multirow[t]{5}{*}{ DDG } & EP-1 & A & $23.36^{\mathrm{b}}$ & $21.31^{\mathrm{b}}$ & $30.28^{\mathrm{b}}$ & $35.96^{\mathrm{b}}$ & $35.51^{\mathrm{b}}$ & $42.98^{\mathrm{de}}$ & $43.80^{\mathrm{d}}$ \\
\hline & & B & $17.54^{\mathrm{c}}$ & $22.29^{\mathrm{b}}$ & $19.97^{\mathrm{c}}$ & $25.49^{d}$ & $31.15^{\mathrm{cd}}$ & $35.12^{\mathrm{f}}$ & $39.35^{\mathrm{e}}$ \\
\hline & $\mathrm{EP}-2$ & & $15.68^{\mathrm{d}}$ & $22.93^{\mathrm{b}}$ & $25.91^{\mathrm{b}}$ & $30.86^{\mathrm{c}}$ & $44.47^{\mathrm{a}}$ & $50.06^{\mathrm{b}}$ & $56.13^{\mathrm{a}}$ \\
\hline & EP-3 & & $6.13^{\mathrm{h}}$ & $14.79^{\mathrm{c}}$ & $19.05^{\mathrm{c}}$ & $18.57^{\mathrm{f}}$ & $25.08^{\mathrm{e}}$ & $35.35^{\mathrm{f}}$ & $40.65^{\mathrm{de}}$ \\
\hline & & Mean & $15.68^{\mathrm{B}}$ & $20.33^{\mathrm{B}}$ & $23.80^{\mathrm{B}}$ & $27.72^{\mathrm{B}}$ & $34.05^{\mathrm{B}}$ & $40.88^{\mathrm{B}}$ & $44.98^{\mathrm{B}}$ \\
\hline \multirow[t]{2}{*}{ DDGS } & EP-4 & & $35.88^{\mathrm{a}}$ & $37.26^{\mathrm{a}}$ & $43.57^{\mathrm{a}}$ & $44.97^{\mathrm{a}}$ & $46.73^{\mathrm{a}}$ & $57.13^{\mathrm{a}}$ & $58.66^{\mathrm{a}}$ \\
\hline & & Mean & $35.88^{\mathrm{A}}$ & $37.26^{\mathrm{A}}$ & $43.57^{\mathrm{A}}$ & $44.97^{\mathrm{A}}$ & $46.73^{\mathrm{A}}$ & $57.13^{\mathrm{A}}$ & $58.66^{\mathrm{A}}$ \\
\hline SEM & & & 0.23 & 1.35 & 6.18 & 1.00 & 4.09 & 5.10 & 4.83 \\
\hline
\end{tabular}

WDG, wet distillers grains; DDG, dried distillers grains; DDGS, dried distillers grains with solubles; DMD, dry matter disappearance; SEM, standard error of means.

${ }^{1}$ Types of ethanol plant, 1 to 4 ; A and B, replication with different sampling date.

${ }^{\text {A-C }}$ Means within a column without a common superscript capital letter differ $(\mathrm{p}<0.05)$.

${ }^{a-i}$ Means within a column without a common superscript letter differ $(\mathrm{p}<0.05)$.

WDG may be a more useful feed ingredient than DDG and DDGS. The price of WDG (KRW 25/kg) is much cheaper than DDG (KRW 280/kg) and DDGS (KRW 270/kg) due to the absence of drying process.

Exp. 2. Effects of dietary WDG on the performance of Hanwoo steers

The BW, ADG, DMI, and FCR of control and WDG treatments are presented in Table 6 . In the middle of the experimental period (42 days), BW of control, WDG 10\% and $20 \%$ were $527.8,518.2$, and $529.9 \mathrm{~kg}$, respectively. Final BW (85 days) of WDG $10 \%(549.7 \mathrm{~kg})$ was numerically lower than that of control $(562.0 \mathrm{~kg})$ and WDG $20 \%(561.8 \mathrm{~kg})$, but there were no significant differences among treatments. Thus, BW of control and WDG treatments did not show any statistical difference during the whole experimental period.

The ADG of control, WDG $10 \%$ and $20 \%$ in phase 1

Table 5. Effects of dietary WDG, DDG, and DDGS on in vitro OMD (\%) from different ethanol plants and sampling dates

\begin{tabular}{|c|c|c|c|c|c|c|c|c|c|}
\hline \multirow{2}{*}{ Contents } & \multirow{2}{*}{\multicolumn{2}{|c|}{ Ethanol plant }} & \multicolumn{7}{|c|}{ In vitro OMD (\%) } \\
\hline & & & $0 \mathrm{~h}$ & $4 \mathrm{~h}$ & $8 \mathrm{~h}$ & $12 \mathrm{~h}$ & $24 \mathrm{~h}$ & $48 \mathrm{~h}$ & $72 \mathrm{~h}$ \\
\hline \multirow[t]{6}{*}{$\overline{\text { WDG }}$} & $E P^{1}-1$ & $\mathrm{~A}$ & $12.02^{\mathrm{e}}$ & $14.82^{\mathrm{de}}$ & $20.45^{\mathrm{c}}$ & $22.86^{\mathrm{f}}$ & $30.76^{\mathrm{de}}$ & $42.78^{\mathrm{de}}$ & $42.98^{\mathrm{e}}$ \\
\hline & & $\mathrm{B}$ & $15.01^{\mathrm{c}}$ & $16.22^{\mathrm{d}}$ & $14.73^{\mathrm{d}}$ & $26.83^{\mathrm{de}}$ & $29.28^{\mathrm{de}}$ & $43.69^{\mathrm{cd}}$ & $43.83^{\mathrm{e}}$ \\
\hline & EP-2 & & $7.55^{\mathrm{f}}$ & $15.59^{d}$ & $19.70^{\mathrm{cd}}$ & $25.51^{\mathrm{e}}$ & $46.89^{\mathrm{a}}$ & $54.27^{\mathrm{a}}$ & $61.33^{b}$ \\
\hline & EP-3 & & $5.32^{\mathrm{f}}$ & $12.62^{\mathrm{ef}}$ & $16.70^{\mathrm{cd}}$ & $22.90^{\mathrm{f}}$ & $37.00^{\mathrm{bc}}$ & $51.41^{\mathrm{b}}$ & $59.68^{\mathrm{b}}$ \\
\hline & EP-4 & & $8.00^{f}$ & $10.59^{\mathrm{f}}$ & $17.62^{\mathrm{cd}}$ & $20.04^{\mathrm{g}}$ & $32.53^{\mathrm{cd}}$ & $51.91^{\mathrm{b}}$ & $52.68^{\mathrm{c}}$ \\
\hline & & Mean & $9.98^{\mathrm{C}}$ & $14.81^{\mathrm{C}}$ & $17.90^{\mathrm{C}}$ & $24.52^{\mathrm{C}}$ & $35.98^{\mathrm{C}}$ & $48.04^{\mathrm{B}}$ & $51.96^{\mathrm{B}}$ \\
\hline \multirow[t]{5}{*}{ DDG } & EP-1 & A & $25.58^{\mathrm{b}}$ & $21.33^{\mathrm{c}}$ & $31.97^{\mathrm{b}}$ & $38.09^{\mathrm{b}}$ & $38.20^{\mathrm{b}}$ & $47.06^{\mathrm{c}}$ & $47.58^{\mathrm{d}}$ \\
\hline & & B & $19.06^{\mathrm{c}}$ & $24.51^{\mathrm{b}}$ & $21.54^{\mathrm{c}}$ & $27.54^{\mathrm{d}}$ & $33.58^{\mathrm{bc}}$ & $38.96^{\mathrm{c}}$ & $42.71^{\mathrm{e}}$ \\
\hline & EP-2 & & $16.40^{\mathrm{cd}}$ & $24.03^{\mathrm{b}}$ & $27.77^{\mathrm{b}}$ & $32.32^{\mathrm{c}}$ & $48.16^{\mathrm{a}}$ & $53.78^{\mathrm{a}}$ & $61.32^{b}$ \\
\hline & EP-3 & & $6.58^{\mathrm{f}}$ & $17.32^{\mathrm{d}}$ & $21.00^{c}$ & $19.81^{\mathrm{g}}$ & $27.96^{\mathrm{e}}$ & $40.45^{\mathrm{de}}$ & $45.70^{\mathrm{de}}$ \\
\hline & & Mean & $16.78^{\mathrm{B}}$ & $21.80^{\mathrm{B}}$ & $25.57^{\mathrm{B}}$ & $29.44^{\mathrm{B}}$ & $36.97^{\mathrm{B}}$ & $45.06^{\mathrm{B}}$ & $49.33^{\mathrm{B}}$ \\
\hline \multirow[t]{2}{*}{ DDGS } & EP-4 & & $37.80^{\mathrm{a}}$ & $40.79^{\mathrm{a}}$ & $46.70^{\mathrm{a}}$ & $47.93^{\mathrm{a}}$ & $49.02^{\mathrm{a}}$ & $63.03^{\mathrm{a}}$ & $65.15^{\mathrm{a}}$ \\
\hline & & Mean & $37.80^{\mathrm{A}}$ & $40.79^{\mathrm{A}}$ & $46.70^{\mathrm{A}}$ & $47.93^{\mathrm{A}}$ & $49.02^{\mathrm{A}}$ & $63.03^{\mathrm{A}}$ & $62.15^{\mathrm{A}}$ \\
\hline SEM & & & 2.42 & 1.60 & 4.92 & 2.85 & 3.96 & 4.97 & 3.29 \\
\hline
\end{tabular}

WDG, wet distillers grains; DDG, dried distillers grains; DDGS, dried distillers grains with solubles; OMD, organic matter disappearance; SEM, standard error of means.

${ }^{1}$ Types of ethanol plant, 1 to 4; A and B, replication with different sampling date.

${ }^{A-C}$ Means within a column without a common superscript capital letter differ $(\mathrm{p}<0.05)$.

${ }^{\mathrm{a}-\mathrm{i}}$ Means within a column without a common superscript letter differ $(\mathrm{p}<0.05)$. 
Table 6. Effects of dietary WDG for TMR ingredients on BW, ADG, DMI, and FCR of Hanwoo steers

\begin{tabular}{lcccc}
\hline Items & Control & $\begin{array}{c}\text { WDG } \\
10 \%\end{array}$ & $\begin{array}{c}\text { WDG } \\
20 \%\end{array}$ & SEM \\
\hline BW (kg) & & & & \\
$0 \mathrm{~d}$ & 497.6 & 488.2 & 499.4 & 14.03 \\
$42 \mathrm{~d}$ & 527.8 & 518.2 & 529.9 & 14.53 \\
$85 \mathrm{~d}$ & 562.0 & 549.7 & 561.8 & 14.68 \\
ADG $(\mathrm{kg} / \mathrm{d})$ & & & & \\
1 to $42 \mathrm{~d}$ & 0.71 & 0.72 & 0.73 & 0.04 \\
43 to $85 \mathrm{~d}$ & 0.82 & 0.75 & 0.76 & 0.04 \\
1 to $85 \mathrm{~d}$ & 0.77 & 0.73 & 0.74 & 0.03 \\
DMI $(\mathrm{kg} / \mathrm{d})$ & & & & \\
1 to $42 \mathrm{~d}$ & 9.12 & 8.95 & 8.61 & 0.15 \\
43 to $85 \mathrm{~d}$ & 9.55 & 9.46 & 9.10 & 0.07 \\
1 to $85 \mathrm{~d}$ & 9.34 & 9.21 & 8.86 & 0.09 \\
FCR & & & & \\
1 to $42 \mathrm{~d}$ & 13.0 & 12.9 & 12.0 & 0.91 \\
43 to $85 \mathrm{~d}$ & 12.9 & 13.4 & 12.1 & 1.02 \\
1 to $85 \mathrm{~d}$ & 13.0 & 13.2 & 12.1 & 0.87 \\
\hline
\end{tabular}

WDG, wet distillers grains; TMR, total mixed rations; BW, body weight; ADG, average daily gain; DMI, dry matter intake; FCR, feed conversion ratio (Feed intake/kg gain); SEM, standard error of means.

( $0.71,0.72$, and $0.73 \mathrm{~kg}$, respectively; 1 to 42 days) and 2 $(0.82,0.75$, and $0.76 \mathrm{~kg}$, respectively; 43 to 85 days) did not show any statistical differences. Thus, ADG of control and WDG treatments did not show any difference during the whole experimental period (WDG, $0.77 \mathrm{~kg} / \mathrm{d}$; DDG, 0.73 $\mathrm{kg} / \mathrm{d}$; DDGS, $0.74 \mathrm{~kg} / \mathrm{d}$ ). Likewise, Larson et al. (1993) reported that WDG making up to $40 \%$ of the diets (DM basis, corn silage and alfalfa hay) did not affect ADG of finishing steers. Uwituze et al. (2010) also reported that there were no differences as a result of roughage source (alfalfa hay and corn silage) in BW and ADG with finishing diets containing 25\% corn and sorghum-based DDG (DM basis). Similarly, when May (2008) fed $25 \%$ corn and sorghum-based DDGS (DM basis) in steam-flaked corn diets, DMI was not affected by the level of DDGS. Maximum inclusion level of WDG as calculated by the feed formulation program (NIAS, Korean feeding standard program for Hanwoo, 2012a) in this study was $28 \%$ (as fed basis) because to meet the requirement of finishing Hanwoo cattle (NIAS, Korean feeding standard for Hanwoo, 2012b) the relatively high concentrations of $\mathrm{CP}$ and low TDN of WDG limit a higher inclusion level.

Average DMI of control and WDG treatments were 9.1 $\mathrm{kg} / \mathrm{d}$ during the whole experimental period, and did not show any statistical difference between control and WDG treatments. In contrast to our results, Larson et al. (1993) reported a linear decrease in DMI when corn-based WDG increased from $0 \%$ to $40 \%$ (DM basis) in the diets, but did not affect ADG. In the whole experimental period (1 to 85 days), FCR of control, WDG $10 \%$ and $20 \%$ were $13.0,13.2$, and $12.1 \mathrm{feed} / \mathrm{gain} / \mathrm{kg}$, respectively. Relatively higher FCR values along with low ADG were observed in our study, probably due to the relatively lower TDN and slightly higher CP concentrations of TMR. According to NIAS (Korean feeding standard for Hanwoo, 2012a), recommended levels of $\mathrm{CP}$ and TDN in feeds of Hanwoo steers at early fattening period are $13 \%$ to $14 \%$ and $69 \%$ to $70 \%$, respectively. In this study, average concentrations of TDN and CP were $64.9 \%$ and $15.5 \%$, respectively. Probably, an unbalanced energy:protein ratio of feeds may lead to high FCR due to the wasted $\mathrm{N}$ metabolism.

In summary of the fattening period trial, BW, ADG, DMI, and FCR of control and WDG treatments during the whole experimental period ( 1 to 85 days) did not show any statistical difference. Thus, the use of WDG up to $20 \%$ (as fed basis) in TMR did not show any negative effect on the performance of Hanwoo steers in early to mid-fattening period.

\section{CONCLUSION}

Considering $\mathrm{CP}$ concentrations, IVDMD and low price, WDG from tapioca and rice (7:3) can be a more useful feed ingredient for ruminants than either DDG or DDGS. The use of WDG from tapioca and rice up to $20 \%$ (as fed basis) in TMR did not show any negative effect on the performance of Hanwoo steers (in BW, ADG, DMI, and FCR) in the initial to mid-fattening period. Therefore, WDG (up to $20 \%$ in TMR, as fed basis) from tapioca and rice (7:3) can be safely used as a feed ingredient for Hanwoo steers.

\section{ACKNOWLEDGMENTS}

This study was supported by 'Cooperative Research Program for Agriculture Science \& Technology Development (Project No. PJ009156)' Rural Development Administration, Republic of Korea. This paper was written as part of Konkuk University's research support program for its faculty on sabbatical leave in 2014.

\section{REFERENCES}

AOAC. 1999. Official Methods of Analysis. 16th ed. Association Official Analytical Chemists, Arlington, VA, USA.

Buckmaster, D. R., P. G. Gunn, S. L. Lake, R. P. Lemenager, and M. C. Claeys. 2008. Co-ensiling of wet distillers grains. Presentation no. 083645. American Society of Agricultural and Biological Engineers Meeting, Providence, RI, USA.

Conrad, H. R., W. P. Weiss, W. O. Odwongo, and W. L. Shockey. 1984. Estimating net energy lactation from components of cell solubles and cell walls. J. Dairy Sci. 67:427-436.

Dooley, F. J., M. Cox, and L. Cox. 2008. Distillers grain handbook: A guide for Indiana producers to using DDGS for 
animal feed. A report for the Indiana Corn Marketing Council. http://incorn.org/2-uncategorised/15-distillers-grain-handbooka-guide-for-indiana-producers-to-using-ddgs-for-animal-feed. Juy 29, 2014

Itabashi, H., T. Kobashi, A. Takenaka, and M. Matsumoto. 1991. Influence of Ethanol on ruminal microbes and Fermentation pattern hydrogenation of unsaturated fatty acids, and Meat quality of beef cattle. Proceedings of the 3rd International Symposium on the Nutrition Herbivores, Penang, Malaysia. pp. 73.

Klopfenstein, T. J., G. E. Erickson, and V. R. Bremer. 2008. BOARD-INVITED REVIEW: Use of distillers by-products in the beef cattle feeding industry. J. Anim. Sci. 86:1223-1231.

Larson, E. M., R. A. Stock, T. J. Klopfenstein, M. H. Sindt, and R. P. Huffman. 1993. Feeding value of wet distillers byproducts for finishing ruminants. J. Anim. Sci. 71:2228-2236.

Lemenager, R. P., T. Applegate, S. Donkin, T. Johnson, S. Lake, M. Neary, S. Radcliffe, B. Richert, A. Schinckel, M. Schutz, and A. Sutton. 2006. The value of distillers grains as a livestock feed. Purdue University Cooperative Extension Service, West Lafayette, IN, USA.

May, M. L. 2008. The Effects of Grain Processing Method, Wet and Dry Distillers Grains with Solubles and Roughage Level on Performance and Carcass Characteristics of Finishing Cattle. MS Thesis. Kansas State Univ., Manhattan, KS, USA.

May, M. L., J. Quinn, N. DiLorenzo, and M. L. Galyean. 2010. Effects of roughage and wet distillers grains with solubles in steam-flaked corn-based substrates on feedlot cattle performance and carcass characteristics. P107 in Proc. Plains Nutr. Council Spring Conf. AREC 10-57, Texas AgriLife Res. and Ext. Center, Amarillo, TX, USA.

McDougall, E. I. 1948. Studies on ruminant saliva. I. The composition and output of sheep's saliva. Biochem. J. 43:99109.

National Institute of Animal Science. 2012a. Korean feeding standard program for Hanwoo. http://www.nias.go.kr/front/ researchUtilizeBoardView.nias?cmCode $=$ M090918001117679 \&boardSeqNum $=8493 \&$ currPage $=1 \&$ attribute $=1 \&$ columnNa me $=\&$ searchStr $=$. Accessed February 13, 2013
National Institute of Animal Science. 2012b. Korean Feeding Standard for Hanwoo. 3rd Ed. Rural Development Administration, Jeonju, Korea.

NRC. 2000. Nutrient Requirements of Dairy Cattle, 6th rev. ed., National Academy Press, Washington, DC, USA.

Quinn, M. J., M. L. May, N. DiLorenzo, C. H. Ponce, D. R. Smith, S. L. Parr, and M. L. Galyean. 2011. Effects of roughage source and distillers grain concentration on beef cattle finishing performance, carcass characteristics, and in vitro fermentation. J. Anim. Sci. 89:2631-2642.

SAS Institute. 2002. SAS User's Guide: Statistics. Ver. 9.01 ed. Statistical Analysis Systems Institute Inc., Cary, NC, USA.

Shurson, J. and S. Noll. 2005. Feed and Alternative Uses for DDGS. In: Proceeding of the 2005 Energy from Agriculture Conference, St. Louis, MO, USA. pp. 14-15.

Smith, D. R., C. H. Ponce, N. DiLorenzo, M. J. Quinn, M. L. May, J. C. MacDonald, M. K. Luebbe, R. G. Bondurant, and M. L. Galyean. 2013. Effects of dietary concentration of wet distillers grains on performance by newly received beef cattle, in vitro gas production and volatile fatty acid concentrations, and in vitro dry matter disappearance. J. Anim. Sci. 91:28362845.

Statistics Korea. http://kostat.go.kr/portal/korea/index.action. Accessed October 1, 2014

Tilley, J. M. and A. R. Terry. 1963. A two-stage technique for the in vitro digestion of forage crops. 18:104-111.

Uwituze, S., G. L. Parsons, M. K. Shelor, B. E. Depenbusch, K. K. Karges, M. L. Gibson, C. D. Reinhardt, J. J. Higgins, and J. S. Drouillard. 2010. Evaluation of dried distillers grains and roughage source in steam-flaked corn finishing diets. J. Anim. Sci. 88:258-274.

Van Soest, P. J., J. B. Robertson, and B. A. Lewis. 1991. Methods for dietary fiber, neutral detergent fiber, and nonstarch polysaccharides in relation to animal nutrition. J. Dairy Sci. 74:3583-3597.

Waldo, G., Nuez Ortin, and Peiqiang Yu. 2009. Nutrient variation and availability of wheat DDGS, corn DDGS and blend DDGS from bioethanol plants. J. Sci. Food Agric. 89:1754-1761. 